\title{
1 Adjusted fatality rates of COVID19 pandemic: a 2 comparison across countries
}

3

4 Carlos Canelo-Aybar ${ }^{1-2}$, Jessica Beltran ${ }^{1}$, Marilina Santero $^{1}$, Pablo Alonso-Coello ${ }^{1-2}$ 5

1- Iberoamerican Cochrane Centre - Department of Clinical Epidemiology and Public

\section{Corresponding author}

\section{Carlos Canelo-Aybar}

ccanelo@santpau.cat

Iberoamerican Cochrane Centre - Department of Clinical Epidemiology and Public Health, Biomedical Research Institute Sant Pau (IIB Sant Pau)

Sant Antonio María Claret 167, 08025 Barcelona, Spain

Telf +34 935537804 
medRxiv preprint doi: https://doi.org/10.1101/2020.05.13.20099796; this version posted May 16, 2020. The copyright holder for this preprint (which was not certified by peer review) is the author/funder, who has granted medRxiv a license to display the preprint in perpetuity.

It is made available under a CC-BY-NC-ND 4.0 International license .

\section{Abstract}

22 Background: A key impact measure of COVID-19 pandemic is the case fatality rate (CFR), but estimating it during an epidemic is challenging as the true number of cases may remain elusive.

Objective: To estimate the CFR applying a delay-adjusted method across countries, exploring differences to simple methods and potential correlation to country level variables.

Methods: Secondary analysis of publicly available data from countries with $\geq 500$ cases by April $30^{\text {th }}$. We calculated CFR adjusting for delay time from diagnosis to death and using simple methods for comparison. We performed a random effects meta-analysis to pooling CFRs for all countries and for those with high testing coverage and low positivity rate. We explored correlation of adjusted CFR with age structure and health care resources at country level.

Results: We included 107 countries and the Diamond Princess cruise-ship. The overall delay adjusted CFR was $2.8 \%(95 \% \mathrm{Cl}: 2.1$ to 3.1$)$ while naive CFR was $5.1 \%(95 \% \mathrm{Cl}: 4.1$ to 6.2$)$. In countries with high testing coverage/low positivity rate the pooled adjusted CFR was $2.1 \%$ (95\% Cl: 1.5 to 3.0$)$, there was a correlation with age over 65 years $(\beta=0.12 ; 95 \% \mathrm{Cl}: 0.06$ to $0.18)$, but not with number of physician or critical care beds. Naive method underestimated the CFR of the CFR with a median of $1.3 \%$ across countries.

Conclusion: Our best estimation of CFR across countries is $2 \%$ and varies according to the aged population size. Modelers and policy makers may consider these results to assess the impact of lockdowns or other mitigation policies. 
medRxiv preprint doi: https://doi.org/10.1101/2020.05.13.20099796; this version posted May 16, 2020. The copyright holder for this preprint (which was not certified by peer review) is the author/funder, who has granted medRxiv a license to display the preprint in perpetuity.

It is made available under a CC-BY-NC-ND 4.0 International license .

\section{Introduction}

The coronavirus disease 2019 (COVID-19) is an infectious illness caused by the severe acute respiratory syndrome coronavirus 2 (SARS-CoV-2), which was first reported in December 2009 in Wuhan, China. The disease has since then spread rapidly through mainland China and worldwide [1]. On March 12th 2020, the COVID-19 outbreak was officially characterized as a pandemic by the World Health Organization (WHO) [2]. As of April 30th, globally, nearly three million confirmed infections have been reported, together with more than 250,000 deaths due to COVID-19 [3]. Travel restrictions and lockdowns have been imposed by many countries as actions to mitigate the epidemic growth, with around three billion people living in in countries with border constraints [4], and countries like India, China, France, Italy, New Zealand, Poland, UK, and Spain have implemented restrictive mass quarantines [5].

During an outbreak, case fatality rate (CFR) provides an estimate of the magnitude of an infectious disease, frequently calculated by dividing cumulative deaths by cumulative cases at any moment (naive method). This estimate should be distinguished from the infectious fatality rate (IFR), which is calculated over the total number of infected people (usually estimated from seroprevalence studies). However, the naive approach is subject to several biases in different directions, including preferential ascertainment of severe cases and reporting delay bias [6]. Ascertainment bias occurs when there are asymptomatic cases or with mild symptoms who are not tested and not included in the denominator, while a delayed reporting bias is due to a tome lag between the moment a case is confirmed to the time of death. This is specially concerning when there is a rapidly increasing incidence [6]. Due to these factors, as the epidemic progresses, and cases are tracked more appropriately, naive estimates may falsely suggest a rise in the CFR, which can increase the public alarm $[7,8]$. 
medRxiv preprint doi: https://doi.org/10.1101/2020.05.13.20099796; this version posted May 16, 2020. The copyright holder for this preprint (which was not certified by peer review) is the author/funder, who has granted medRxiv a license to display the preprint in perpetuity.

It is made available under a CC-BY-NC-ND 4.0 International license .

As an example, of the limitations described above, during the current COVID-19 pandemic the WHO initially reported a CFR of $2 \%$ in a press conference on January 29; this estimate was subsequently updated up to $3.4 \%$ on March 3 , suggesting and increase trend on the naive estimate. These calculations were further limited by the fact that the different CFRs should not directly be averaged across countries, as each country will likely have a different testing coverage, age structure or healthcare capacity, all factors that will have an impact in the number of fatalities.

Given the relevance of obtaining a reliable estimation of the fatality rate during the COVID-19 outbreak, we aim to aim to provide more accurate estimations of the COVID-19 CFR across countries using previously published methods(7), and standard pooling meta-analysis techniques. Finally, we will also explore the potential correlation to country level variables.

\section{Material and Methods}

\subsection{Data sources}

This is a secondary analysis of public available data from several sources including the situation reports prepared by WHO [9], the John Hopkins University interactive track map (https://coronavirus.jhu.edu/map.html) which compiles data from several public sources [10] and the Our World in Data repository which also contains testing statistics

87 (https://ourworldindata.org/coronavirus) [11]. We obtained data about population size and proportion over 65 years old from the World Bank demographics statistics [12], the number of critical care beds from previous published studies[13, 14], and the number of healthcare workers from the World Health Organization observatory [15].

\subsection{Inclusion criteria}


medRxiv preprint doi: https://doi.org/10.1101/2020.05.13.20099796; this version posted May 16, 2020. The copyright holder for this preprint (which was not certified by peer review) is the author/funder, who has granted medRxiv a license to display the preprint in perpetuity.

It is made available under a CC-BY-NC-ND 4.0 International license .

We considered data from countries with at least 500 of reported cases with the SARS-

Cov-2 by April 30th. This threshold was based in our sample size calculation to estimate a single population proportion of $3 \%$ with a $95 \%$ confidence interval and a margin of error of $+/-1.5 \%$ [16].

\subsection{Fatality rate estimates}

We collected data per country on the total number of confirmed cases, total number of cases recovered, and total number of deaths from January 22 to April 30th. Based on these three variables we estimated the CFR using the following methods: available by the authors (https://github.com/thimotei/cCFRDiamondPrincess) based in

Where $u_{t}$ is the correction factor applied to the denominator (cumulative number of cases), to estimate the proportion with known outcome, $c$ is the daily case incidence at time $i$ and $\mathrm{f}$ is the proportion of cases with delay between onset or hospitalization and death [18].

$$
\mathrm{u}_{t}=\frac{\sum_{i=0}^{t} \sum_{j=0}^{\infty} c_{i}-{ }_{j} f_{j}}{\sum_{i=0}^{t} c i}
$$
mean of 13 days, based on an analysis of 39 cases of COVID-19 from the city of Wuhan, China [19]. 
medRxiv preprint doi: https://doi.org/10.1101/2020.05.13.20099796; this version posted May 16, 2020. The copyright holder for this preprint (which was not certified by peer review) is the author/funder, who has granted medRxiv a license to display the preprint in perpetuity.

It is made available under a CC-BY-NC-ND 4.0 International license.

116 ii) For comparison purposes we the naive CFR (nCFR), which was obtained by dividing the cumulative number of deaths and recovered patients.

To pool the CFR across countries, we performed a meta-analysis of proportions using a generalized linear mixed random model (which assumes a distribution of different true estimates across entities) with a logit transformation, and the Clopper Pearson method to estimate the confidence intervals for each observation [20]. We assessed the heterogeneity in the estimated CFR across countries by visual inspections of the forest plots, as the $Q$ statistic and the I-square parameter are not recommended for to evaluate inconsistency for proportion meta-analysis. We performed the analysis using the package metaprop in the $\mathrm{R}$ statistical platform, version 3.6.2. of COVID-19 testing, which we defined for purpose of our analysis as having performed more than 10 tests per thousand habitants and maintaining a rate of positive tests lower than $10 \%$, and as a sensitivity analysis we performed the same analysis for countries with less than $5 \%$ of positivity rate. Countries with these characteristics are more likely able to maintain an acceptable surveillance of positive cases as the outbreak progresses and, thus typically provide more reliable CFR estimates. ecological analysis to assess if there were a positive correlation between the dCFR and the proportion of population over 65 years old, or a negative correlation with the number of critical 
medRxiv preprint doi: https://doi.org/10.1101/2020.05.13.20099796; this version posted May 16, 2020. The copyright holder for this preprint (which was not certified by peer review) is the author/funder, who has granted medRxiv a license to display the preprint in perpetuity.

It is made available under a CC-BY-NC-ND 4.0 International license .

141 regression analysis after a logarithmic transformation of the delay adjusted CFRs, and a

142 multivariate regression analysis including variables with a $p$ value $<0.10$. We tested the normality

143 of residuals by producing a kernel density plot and homoscedasticity by plotting residuals versus

144 fitted (predicted) values.

Finally, we graphically plotted the progression of the nCFR and the dCFR over time, since the seventh day after the first reported death, for three countries that showed a flattened epidemic curve over time (New Zealand, South Korea, and Germany).

\section{Results}

We included data from a total of 107 countries with more than 500 confirmed cases reported, most of them from Europe (39), and Asia (32). We also included data from the 712 cases among passengers of the Diamond Princess cruise ship. As of April $30^{\text {th }}$, the number of cumulative cases reported ranged from 539 (Georgia) to 1,069,424 (United States), while the cumulative number of deaths reported ranged from 2 (Djibouti) to 62,996 (United States). The countries with the largest proportion of population over 65 years old were Japan and Italy; the countries with the largest number of critical beds per habitants were the United States, Germany and Turkey; and the countries with the largest number of physicians were Cuba, Sweden and Austria. (Supplementary Table S1).

We identified a subset of 26 countries, together with the Diamond Princess cohort as having large number of tests performed and low positivity rate. Among these countries, the one with the highest number of tests performed was Iceland (120.4 tests per thousand people), and the lowest was South Korea (10.7 tests per thousand people). The highest positivity rate was observed in Singapore (9.7\%) and the lowest in Hong Kong (0.8\%). 
medRxiv preprint doi: https://doi.org/10.1101/2020.05.13.20099796; this version posted May 16, 2020. The copyright holder for this preprint (which was not certified by peer review) is the author/funder, who has granted medRxiv a license to display the preprint in perpetuity.

It is made available under a CC-BY-NC-ND 4.0 International license .

European region apart from Mexico (20.9\%), Honduras (15.3\%) and Brazil (15.2\%). The overall pooled naive estimates underestimated the CFR by $35 \%$, showing a rate of $2.8 \%(95 \% \mathrm{Cl}: 2.3$ to

3.3) across countries. The difference between the nCFR and the dCFR across countries had a median of $1.3 \%$ and ranged between $0.1 \%$ (Hong Kong, Iceland, China) to than $12 \%$ (Mexico), being correlated to the intensity of the outbreak progression. The recovery method showed a much higher fatality rate (CFR $16.0 \% ; 95 \% \mathrm{Cl} 11.9 \%$ to $21.3 \%$ ), but many of the individual values per country were implausible (over $50 \%$ ), precluding the possibility of further analysis using this method (Supplementary Figure S1).

In the subgroup with large testing coverage, the dCFR ranged from $0.2 \%$ (Singapore) to 9.6\% (Canada). Our initial pooled estimation was 2.3\% (95\% Cl 1.6\% to 3.3\%) (Supplementary

file figure S2), but at the visual assessment of the forest plot there was important heterogeneity with the largest values for countries like Denmark (6.6\%), Slovenia (7.4) and in particular for Canada (9.6\%). The dCFR from Canada was excluded in a subsequent analysis because their confidence interval did not overlap with any the estimates of the remaining countries, this analysis showed a pooled dCFR of $2.1 \%(95 \% \mathrm{Cl} 1.5$ to 3.0$)$, and a prediction interval that ranged from $0.4 \%$ to $10.9 \%$ (Figure 2). Our sensitivity analysis including countries with positivity rate $\leq 5 \%$ showed a consistent result with a pooled dCFR of $2.0 \%(95 \% \mathrm{Cl} 1.5$ to show an association between the dCFR and the number of critical care beds per million people $(\beta=0.01 ; 95 \% \mathrm{Cl}=-0.07$ to $0.08, p$ value $=0.85)$; but we observed and association with the number of physicians per thousand people $(\beta=0.52 ; 95 \% \mathrm{Cl}=0.18$ to $0.87, p$ value $=0.004)$ and with the proportion of population over 65 years old $(\beta=0.11 ; 95 \% \mathrm{Cl} 0.06$ to $0.18, p$ value 
medRxiv preprint doi: https://doi.org/10.1101/2020.05.13.20099796; this version posted May 16, 2020. The copyright holder for this preprint (which was not certified by peer review) is the author/funder, who has granted medRxiv a license to display the preprint in perpetuity.

It is made available under a CC-BY-NC-ND 4.0 International license.

physician ( $\beta=0.26 ; 95 \% \mathrm{Cl}=-0.09$ to $0.63, p$ value 0.14 ), while the association with age over 65 years remained statistically significant $(\beta=0.09 ; 95 \% \mathrm{Cl}=0.02$ to $0.16, p$ value $=0.01)$.

We plotted the nCFR and dCFR over time for New Zealand, South Korea, and Germany. In the three examples, we observed that, as the epidemic progressed over time the naive estimations showed an increasing pattern, from very low rates to rates near the adjusted estimations, with a lag of approximately one to two weeks (Figure 4).

\section{Discussion}

The most remarkable result to emerge from the data is that our best approximation for the COVID-19 CFR across countries with a good testing coverage is of $2 \%$. This estimation is an average of potentially different true CFR as they might vary depending on countries' age structure (higher in countries with aged populations). Accordingly, this estimation based on the available data is lower than the reported by the WHO of around 3.4\%.but still 20 times higher than the reported CFR for other diseases like seasonal influenza (0.01\%) [21]. Moreover, it is lower than other recent coronavirus epidemics as the Severe Acute Respiratory Syndrome (SARS) with a fatality rate of 10\% [22], or the Middle East Respiratory Syndrome (MERS) with an even higher mortality rate of around 34\% [23]. We selected countries with a high testing coverage for our primary analysis to provide more robust results, however, further population seroprevalence studies will be required to estimate the infectious fatality rate which in simulation studies have been estimated to be lower than $1 \%$ [24].

Importantly, we have verified a positive correlation with the population age structure. Larger delay adjusted CFRs were observed in countries like Canada, Slovenia or Denmark which have a high proportion of people over 65 years old [12]. In addition, it have been reported that the outbreak specifically affected the older segment of the population in Canada, where more than $90 \%$ of who have died were over 60 years old, and nearly half of the deaths occurred in 
medRxiv preprint doi: https://doi.org/10.1101/2020.05.13.20099796; this version posted May 16, 2020. The copyright holder for this preprint (which was not certified by peer review) is the author/funder, who has granted medRxiv a license to display the preprint in perpetuity.

It is made available under a CC-BY-NC-ND 4.0 International license.

215 long term care homes [25], something that has been also reported in Slovenia [26]. On the other

216 side, Singapore had the smallest CFR, partly due to the smaller proportion of older people (11\%),

217 and because the outbreak concentrated in younger migrant workers.

We showed that naïve CFR underestimates corrected estimates by a median of $1.3 \%$,

with the magnitude of this difference being correlated to the epidemic curve growth. This observation should be considered by policy makers when communicating the consequences of the outbreak. This bias, due to the calculation method, has been previously reported during the SARS epidemic, in which naïve fatality rate increased over time, leading some to conclude that was more lethal than it resulted to be. The public health impact of inaccurate estimates, resulting in misinformation and conflicting messages, can therefore exacerbate public alarm [7]. death an reported CFR for 82 countries outside China of $4.24 \%$, but this was calculated using a fairly simplistic method, based on the number of cases of 13 days previous to the assessment date [27]. Another study collected data from several surveillance sources of cases from mainland China only, adjusting for under-ascertainment, and time delay; the authors obtained a CFR of $1.38 \%$, increasing to $6.4 \%$ in those older than 64 years [24]. The Centre of Evidence Based Medicine used a meta-analytic approach to calculate a prediction interval across countries of between $0.84 \%$ to $8.67 \%$. The authors did not provide a pooled estimate due to the large heterogeneity observed. However, by using a fixed effect model the authors assumed the existence of an only true value, an assumption that is not appropriate to account for different true CFR across countries, they relied in naive estimates, and did not considering testing coverage in their assessment. 
medRxiv preprint doi: https://doi.org/10.1101/2020.05.13.20099796; this version posted May 16, 2020. The copyright holder for this preprint (which was not certified by peer review) is the author/funder, who has granted medRxiv a license to display the preprint in perpetuity.

It is made available under a CC-BY-NC-ND 4.0 International license .

samples from approximately 1,000 inhabitants of the German town of Gangelt (population of

12,529 people), estimating an infection rate of $14 \%$, and a fatality rate of $0.37 \%$. Another study

conducted in the Santa Clara County, California, United States, found a population-weighted prevalence that ranged from $2.5 \%$ to $4.2 \%$ and an infectious fatality rate of $0.12 \%$ to $0.2 \%$ [28].

However, these results have received some criticism related to the potential large false positive results from serology tests, and the recruitment method employed that might have overestimated the number of infected people. positive test result and not in the real number of infected people, overestimating the CFR. Asymptomatic cases and mild symptomatic patients are not routinely tested as it is underscored by recent publications. In a large-scale COVID-19 diagnostic testing in Iceland with 9,199 persons, found that $43 \%$ of positive cases were asymptomatic at the time of testing [22]. In another study, from a total of 215 pregnant women, 29 of 33 (88\%) who were SARS-CoV-2 positive at admission were asymptomatic [29]. Although, the number of tests performed might differ from the number of individuals tested, and the distinction is not always clear in public data countries with a large number of tests performed and low positive rate in our main analysis, has likely reduced the impact of the bias due to the ascertainment of cases.

We should also consider the bias due to underreporting of the cause of death, which goes in the opposite direction (underestimating CFR). For example, China has recently revised its death tolls, on April 17, adding 1,300 fatalities to its initial official count for the city of Wuhan; due to the inclusion of deaths that occurred at home or at institutions [30]. Similarly, in Madrid,

262 Spain, around 4,100 death cases occurred among elder people in long term care homes who reported symptoms compatible with COVID-19 and that were not accounted in official reports 
medRxiv preprint doi: https://doi.org/10.1101/2020.05.13.20099796; this version posted May 16, 2020. The copyright holder for this preprint (which was not certified by peer review) is the author/funder, who has granted medRxiv a license to display the preprint in perpetuity.

It is made available under a CC-BY-NC-ND 4.0 International license.

previous years, as in the Guayas region of Ecuador in which an excess of more than 6,000 deaths

was observed, probably be related to the COVID-19 outbreak [32]. Based in this approach,

approximately a $25 \%$ of the comparative excess mortality could be also attributed to COVID-19

in countries like Germany or Portugal [33].

We consider our calculations also have strengths, compared with previous estimation across countries, because: 1 ) we included countries with more than 500 confirmed cases which making calculations more stable, 2) we used an appropriate method for pooling proportions, including a random model that considers the different true estimates across different settings, time between diagnosis and death, and 4) we only included in our main analysis countries with good testing coverage, which might reduce the impact of the different biases due to ascertainment of cases.

\subsection{Conclusion}

In conclusion, assessing the fatality rate of COVID-19 is critical to determine the appropriateness of mitigation strategies, as well as to enable forecasting of healthcare requirements as the epidemic unfolds. Thus, one urgent need is to conduct large high quality seroprevalence studies [34]. Meanwhile, our findings contributes to the literature providing a good approximation of the true fatality rate across countries based in more appropriate methods and taking into account the testing coverage and positivity rate. Until more robust estimates are available, a CFR of $2 \%$ might be used for policy makers for comparability. Our study shows that naive estimation of CFR underestimates the potential threat of COVID-19, and although use of such methods are clearly easier to communicate to policy makers and the public, their use could be misleading for the deployment of health systems responses. 
medRxiv preprint doi: https://doi.org/10.1101/2020.05.13.20099796; this version posted May 16, 2020. The copyright holder for this preprint (which was not certified by peer review) is the author/funder, who has granted medRxiv a license to display the preprint in perpetuity.

It is made available under a CC-BY-NC-ND 4.0 International license.

290 Carlos Canelo-Aybar, Jessica Beltran: Conceptualization, Carlos Canelo-Aybar, Jessica Beltran, Marilina

291 Santero, Pablo Alonso-Coello: Methodology; Carlos Canelo-Aybar: Data Curation and Analysis; Carlos

292 Canelo-Aybar, Jessica Beltran: Writing-Original Draft; Marilina Santero, Pablo Alonso-Coello: Writing -

293 Review \& Editing; Pablo Alonso-Coello: Supervision.

294 Funding

295 This research did not receive any specific grant from funding agencies in the public, commercial,

296 or not-for-profit sectors.

297

\section{Conflict of interest}

298

The authors declare that there are no conflicts of interest 
medRxiv preprint doi: https://doi.org/10.1101/2020.05.13.20099796; this version posted May 16, 2020. The copyright holder for this preprint (which was not certified by peer review) is the author/funder, who has granted medRxiv a license to display the preprint in perpetuity.

It is made available under a CC-BY-NC-ND 4.0 International license .

Figure 1. Meta-analysis of the delay adjusted CFR across countries with high testing coverage and low positivity rate*

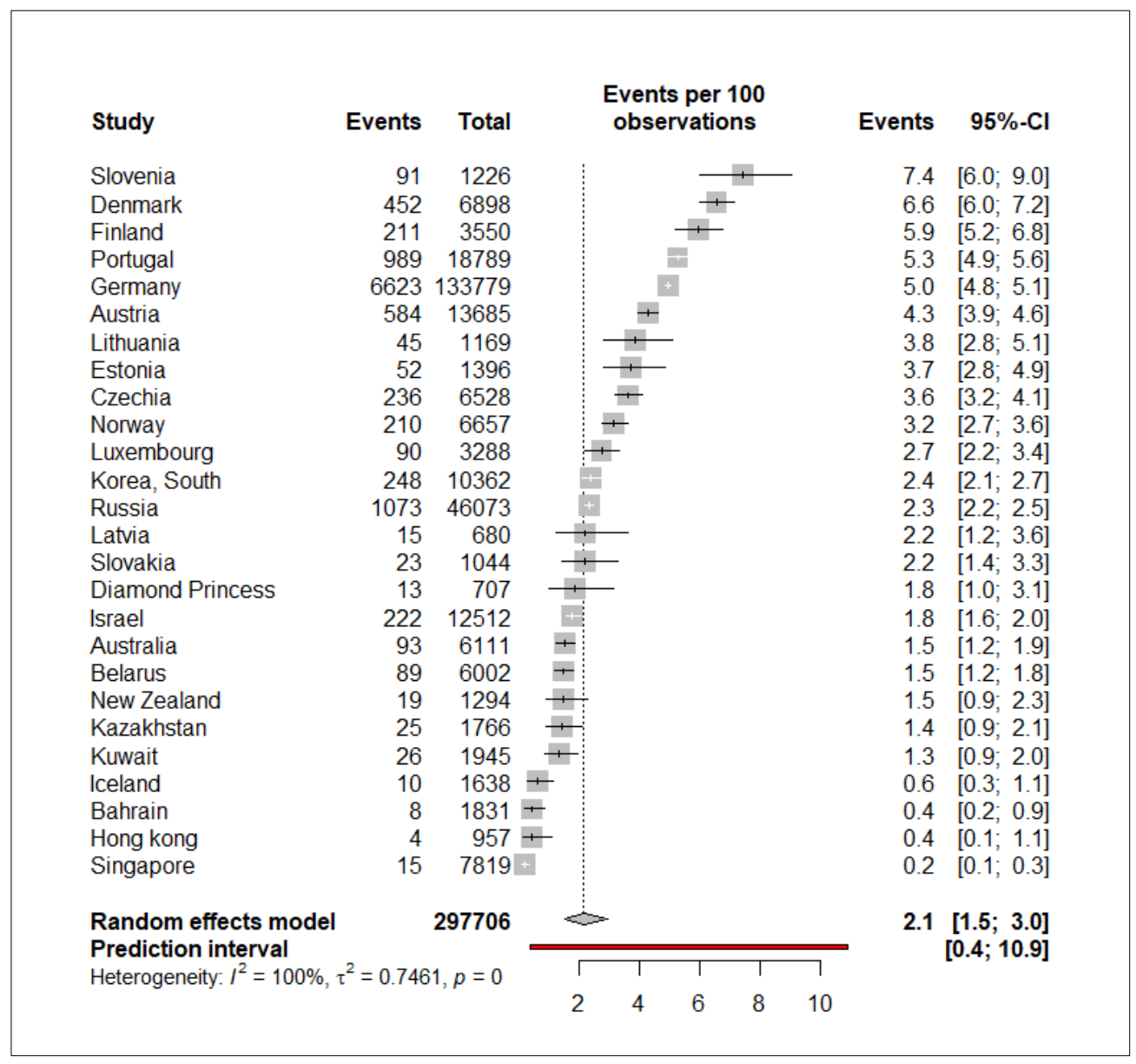

*Analysis excluding Canada due to having an outlier value. 
medRxiv preprint doi: https://doi.org/10.1101/2020.05.13.20099796; this version posted May 16, 2020. The copyright holder for this preprint (which was not certified by peer review) is the author/funder, who has granted medRxiv a license to display the preprint in perpetuity.

It is made available under a CC-BY-NC-ND 4.0 International license.

Figure 2. Overall meta-analysis across countries of the naive and delay adjusted CFR.

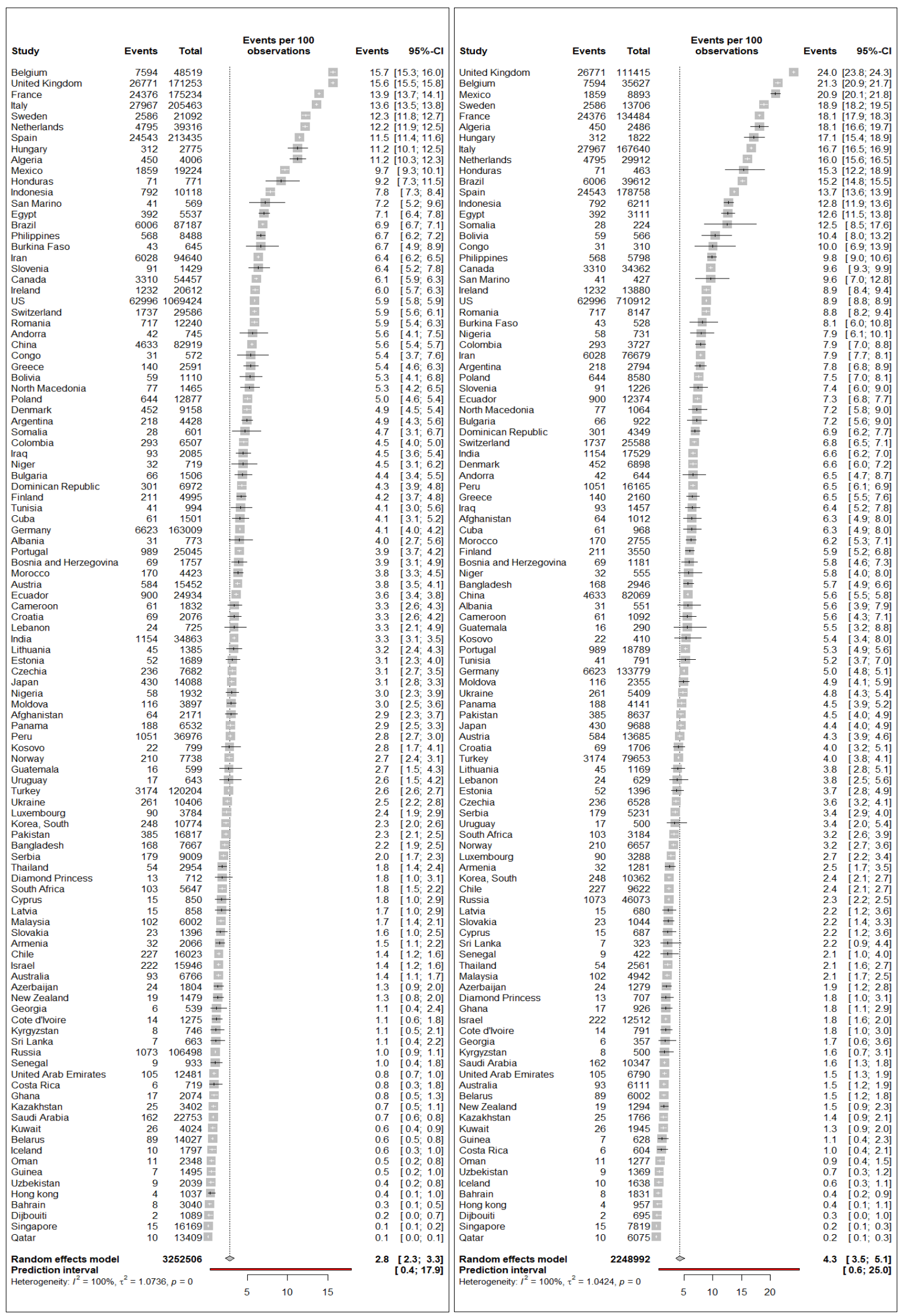

A: Naive method.

B: Delay adjusted method 
medRxiv preprint doi: https://doi.org/10.1101/2020.05.13.20099796; this version posted May 16, 2020. The copyright holder for this preprint (which was not certified by peer review) is the author/funder, who has granted medRxiv a license to display the preprint in perpetuity.

It is made available under a CC-BY-NC-ND 4.0 International license .

Figure 3. Linear regression plot for proportion of population over 65 years and the delay adjusted CFR.

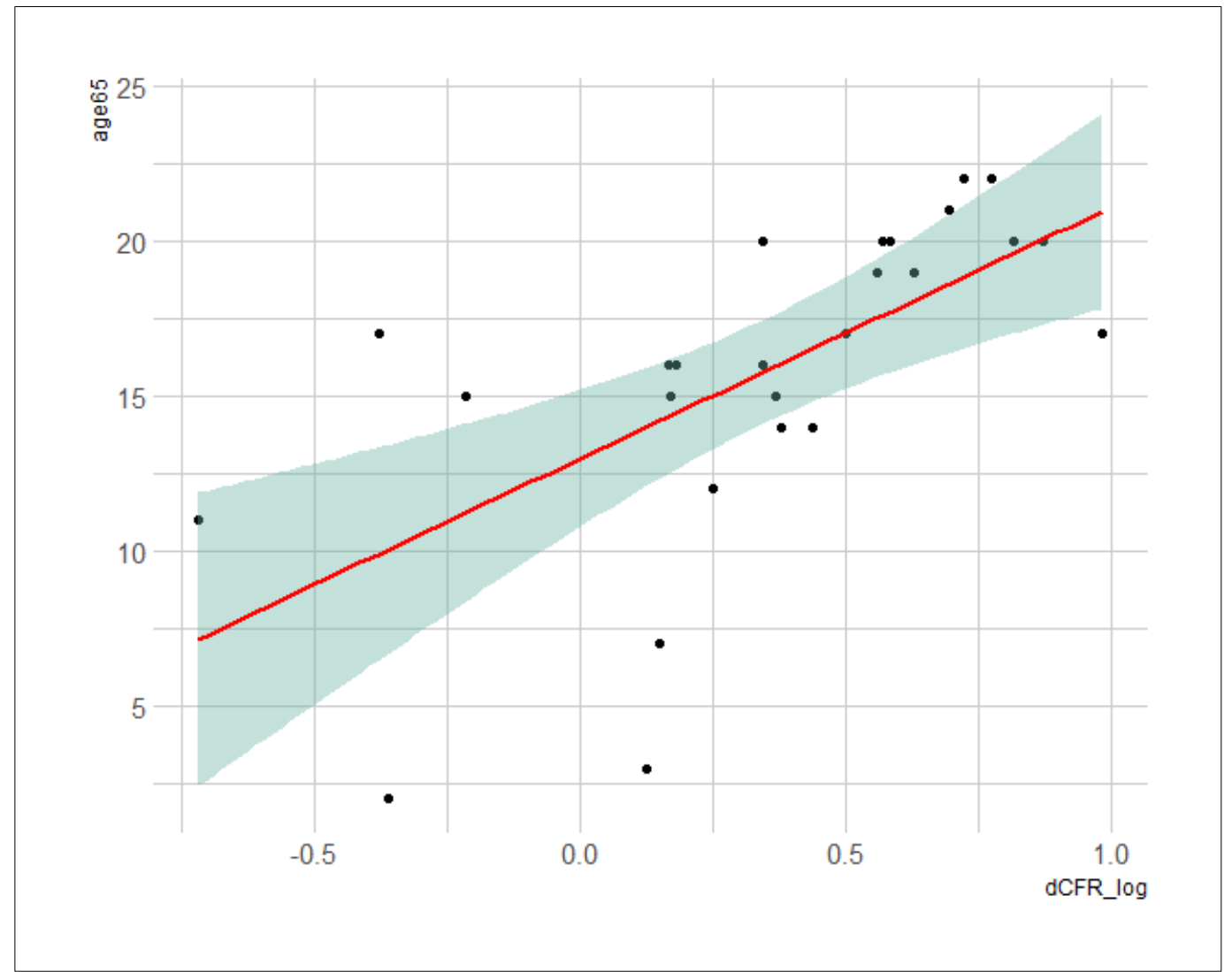


medRxiv preprint doi: https://doi.org/10.1101/2020.05.13.20099796; this version posted May 16, 2020. The copyright holder for this preprint (which was not certified by peer review) is the author/funder, who has granted medRxiv a license to display the preprint in perpetuity.

It is made available under a CC-BY-NC-ND 4.0 International license .

Figure 4. Fatality rate curve over time using the naive and the delay adjusted method for selected countries.
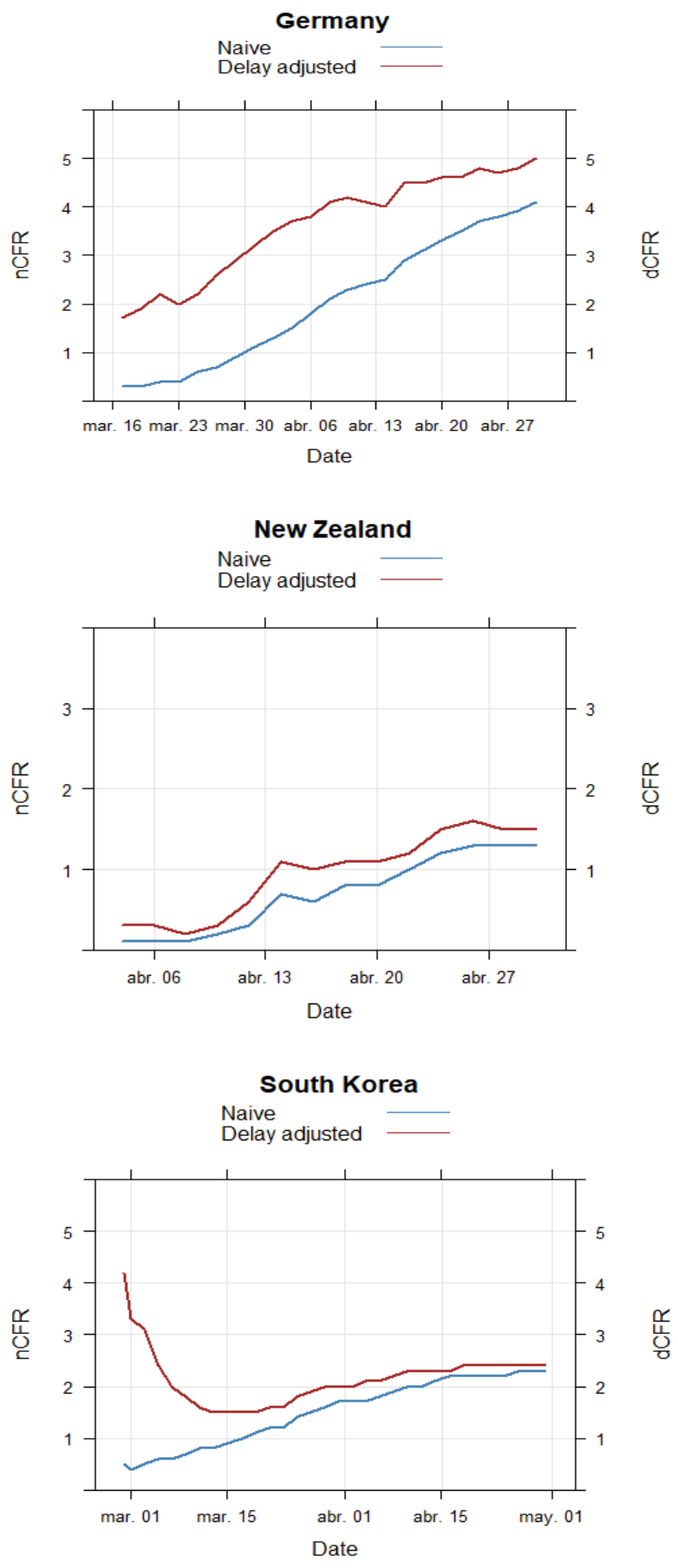
medRxiv preprint doi: https://doi.org/10.1101/2020.05.13.20099796; this version posted May 16, 2020. The copyright holder for this preprint (which was not certified by peer review) is the author/funder, who has granted medRxiv a license to display the preprint in perpetuity.

It is made available under a CC-BY-NC-ND 4.0 International license .

\section{References}

[1] Wang C, Horby PW, Hayden FG, Gao GF. A novel coronavirus outbreak of global health concern. Lancet. 2020;395(10223):470-3.

[2] World Health Organization. WHO announces COVID-19 outbreak a pandemic [Internet]; 2020 [cited 2020Apr21]. Available from: http://www.euro.who.int/en/health-topics/healthemergencies/coronavirus-covid-19/news/news/2020/3/who-announces-covid-19-outbreak-apandemic.

[3] WHO Director-General's opening remarks at the media briefing on COVID-19 - 17 April 2020 [Internet]. World Health Organization. World Health Organization; [cited 2020Apr21]. Available from: https://www.who.int/dg/speeches/detail/who-director-general-s-opening-remarks-at-the-mediabriefing-on-covid-19---17-april-2020.

[4] Salcedo A, Yar S, Cherelus G. Coronavirus Travel Restrictions, Across the Globe [Internet]. The New York Times. The New York Times; 2020 [cited 2020Apr21]. Available from:

https://www.nytimes.com/article/coronavirus-travel-restrictions.html.

[5] Juliana Kaplan LF. A third of the global population is on coronavirus lockdown - here's our constantly updated list of countries and restrictions [Internet]. Business Insider. Business Insider; 2020 [cited 2020Apr21]. Available from: https://www.businessinsider.com/countries-on-lockdowncoronavirus-italy-2020-3.

[6] Lipsitch M, Donnelly CA, Fraser C, Blake IM, Cori A, Dorigatti I, et al. Potential Biases in Estimating Absolute and Relative Case-Fatality Risks during Outbreaks. PLoS neglected tropical diseases. 2015;9(7):e0003846.

[7] Ghani AC, Donnelly CA, Cox DR, Griffin JT, Fraser C, Lam TH, et al. Methods for estimating the case fatality ratio for a novel, emerging infectious disease. American journal of epidemiology. 2005;162(5):479-86.

[8] Cable News Network (CNN). SARS becoming deadlier: officials. (http:/www.cnn.com/2003/HEALTH/04/24/sars.death/). April 25, 2003.

[9] COVID-19 situation reports [Internet]. World Health Organization. World Health Organization; [cited 2020Apr21]. Available from: https://www.who.int/emergencies/diseases/novelcoronavirus-2019/situation-reports.

[10] Dong E, Du H, Gardner L. An interactive web-based dashboard to track COVID-19 in real time. The Lancet Infectious diseases. 2020.

[11] Hasell J. Coronavirus (COVID-19) Testing - Statistics and Research [Internet]. Our World in Data. [cited 2020May8]. Available from: https://ourworldindata.org/coronavirus-testing\#thenumber-of-tests-per-confirmed-case.

[12] Population, total [Internet]. Data. [cited 2020Apr21]. Available from: https://data.worldbank.org/indicator/SP.POP.TOTL.

[13] Phua J, Faruq MO, Kulkarni AP, Redjeki IS, Detleuxay K, Mendsaikhan N, et al. Critical Care Bed Capacity in Asian Countries and Regions. Critical care medicine. 2020.

[14] Rhodes A, Ferdinande P, Flaatten H, Guidet B, Metnitz PG, Moreno RP. The variability of critical care bed numbers in Europe. Intensive care medicine. 2012;38(10):1647-53.

15. The 2018 update, Global Health Workforce Statistics, World Health Organization, Geneva (http://www.who.int/hrh/statistics/hwfstats/).

16. Dhand, N. K., \& Khatkar, M. S. (2014). Statulator: An online statistical calculator. Sample Size Calculator for Estimating a Single Proportion. Accessed 9 May 2020 at http://statulator.com/SampleSize/ss1P.html.

[17] Nishiura H, Klinkenberg D, Roberts M, Heesterbeek JA. Early epidemiological assessment of the virulence of emerging infectious diseases: a case study of an influenza pandemic. PloS one.

2009;4(8):e6852. 
medRxiv preprint doi: https://doi.org/10.1101/2020.05.13.20099796; this version posted May 16, 2020. The copyright holder for this preprint (which was not certified by peer review) is the author/funder, who has granted medRxiv a license to display the preprint in perpetuity. It is made available under a CC-BY-NC-ND 4.0 International license.

[18] Russell TW, Hellewell J, Jarvis Cl, van Zandvoort K, Abbott S, Ratnayake R, et al. Estimating the infection and case fatality ratio for coronavirus disease (COVID-19) using age-adjusted data from the outbreak on the Diamond Princess cruise ship, February 2020. Euro surveillance : bulletin Europeen sur les maladies transmissibles = European communicable disease bulletin. 2020;25(12). [19] Linton NM, Kobayashi T, Yang Y, Hayashi K, Akhmetzhanov AR, Jung SM, et al. Incubation Period and Other Epidemiological Characteristics of 2019 Novel Coronavirus Infections with Right Truncation: A Statistical Analysis of Publicly Available Case Data. Journal of clinical medicine. 2020;9(2).

[20] Nyaga VN, Arbyn M, Aerts M. Metaprop: a Stata command to perform meta-analysis of binomial data. Archives of public health = Archives belges de sante publique. 2014;72(1):39.

[21] Morbidity and Mortality Weekly Report (MMWR) [Internet]. Centers for Disease Control and Prevention. Centers for Disease Control and Prevention; [cited 2020Apr23]. Available from: https://www.cdc.gov/mmwr/preview/mmwrhtml/mm5933a1.htm.

[22] Gudbjartsson DF, Helgason A, Jonsson H, Magnusson OT, Melsted P, Norddahl GL, et al. Spread of SARS-CoV-2 in the Icelandic Population. The New England journal of medicine. 2020. [23] WHO. Middle East respiratory syndrome coronavirus (MERS-CoV). Available at: https://www.who.int/emergencies/mers-cov/en/.[Accessed: 29.02.2020].

[24] Verity R, Okell LC, Dorigatti I, Winskill P, Whittaker C, Imai N, et al. Estimates of the severity of coronavirus disease 2019: a model-based analysis. The Lancet Infectious diseases. 2020.

[25] Embensadoun. Nearly half of Canada's COVID-19 deaths linked to long-term care facilities: Tam [Internet]. Global News. Global News; 2020 [cited 2020Apr23]. Available from: https://globalnews.ca/news/6811726/coronavirus-long-term-care-deaths-canada/.

[26] COVID-19 \& Slovenia, Afternoon 15 April: Numbers; Gloves No Longer Mandatory; Random Testing Announced [Internet]. slovenia. [cited 2020Apr23]. Available from: https://www.totalslovenia-news.com/politics/6057-covid-19-slovenia.

[27] Wilson N, Kvalsvig A, Barnard LT, Baker MG. Case-Fatality Risk Estimates for COVID-19 Calculated by Using a Lag Time for Fatality. Emerging infectious diseases. 2020;26(6).

[28] Bendavid E MB, Sood N, Shah S, Ling E, Bromley-Dulfano R, et al COVID-19 Antibody Seroprevalence in Santa Clara County, California. medRxiv 2020041420062463 [pre-print]. [29] Sutton D, Fuchs K, D'Alton M, Goffman D. Universal Screening for SARS-CoV-2 in Women Admitted for Delivery. The New England journal of medicine. 2020.

[30] Coronavirus: China outbreak city Wuhan raises death toll by $50 \%$ [Internet]. BBC News. BBC; 2020 [cited 2020Apr23]. Available from: https://www.bbc.com/news/world-asia-china-52321529.

[31] Allen N. Spain's coronavirus deaths pass 14,500, but real toll may be bigger [Internet]. Reuters. Thomson Reuters; 2020 [cited 2020Apr23]. Available from:

https://www.reuters.com/article/us-health-coronavirus-spain/spains-coronavirus-deaths-pass14500-but-real-toll-may-be-bigger-idUSKBN21Q190.

[32] Collyns D. Ecuador's death rate soars as fears grow over scale of coronavirus crisis [Internet]. The Guardian. Guardian News and Media; 2020 [cited 2020Apr23]. Available from:

https://www.theguardian.com/world/2020/apr/17/coronavirus-death-toll-in-ecuador-could-be-farhigher-than-thought.

[33] Understanding excess mortality [Internet]. The Health Foundation. [cited 2020May9]. Available from: https://www.health.org.uk/news-and-comment/charts-andinfographics/understanding-excess-mortality-the-fairest-way-to-make-international-comparisons.

[34] Mallapaty S. Antibody tests suggest that coronavirus infections vastly exceed official counts [Internet]. Nature News. Nature Publishing Group; 2020 [cited 2020Apr23]. Available from: https://www.nature.com/articles/d41586-020-01095-0. 